\title{
The application of fuzzy-PID control in PV generation of DC-DC converter
}

\author{
WANG Yanlong ${ }^{1}$,YANG Xuhong ${ }^{1}$, LI Haoran $^{1}$ \\ Automatic Engineering of Shanghai University of Electric Power \\ Shanghai,China \\ E-mail:wangyanlong818@139.com
}

Keywords: PV; fuzzy-PID control;MPPT; constant voltage output

\begin{abstract}
In order to implement the optimal utilization of energy and stable running of system in the stand-alone PV generation system of microgrid,the control mode of DC-DC converter has to switch frequently between MPPT control and constant voltage control.And the two modes have its own control strategy and the whole control strategy is complicated.The paper proposes a new algorithm based on fuzzy-PID control,which utilizes the same fuzzy rules.It can not only complete the MPPT control,but also complete the constant voltage output control.And the control strategy of DC-DC converter in PV generation interfaces is simplified and the stability of system is improved.Finally,the simulation result shows that the control strategy is correct and effective.
\end{abstract}

\section{Introduction}

With the development of social economy,the demand of power energy is higher and higher.Satisfying the energy demand and protecting the environment and developing low-carbon economy are the urgent problems that all governments have to solve.The solar energy is ideal and renewable energy which has attracted the attention of society generally [1].The stand-alone PV generation system of microgrid in this paper shown in fig.1 mainly includes:solar cell,battery,unidirectional DC-DC converter,bidirectional DC-DC converter and local loads [2].PV cell accesses to dc bus through DC-DC converter.Since the output power of PV cell is mainly related to the external environment(including intensity and temperature) and loads,so the output power changes largely and the system can not store energy. Therefore,the battery which can store and regulate the power,has to be provided to the system. The battery accesses to dc bus through the DC-DC converter of battery to implement the charging and discharging of battery. The control mode of DC-DC converter has to switch frequently between MPPT control and constant voltage control,and the two modes have its own control strategy and the whole control strategy is complicated [3].The paper proposes a new algorithm based on fuzzy-PID control,which utilizes the same fuzzy rules.It can not only complete the MPPT control,but also complete the constant voltage output control.And the control strategy of DC-DC converter in PV generation interfaces is simplified and the stability of system is improved. The proposed algorithm is simulated in Simulink and the result shows that the new algorithm can not only implement the PV MPPT control,but also implement the constant voltage output control.And a good control performance is obtained finally.

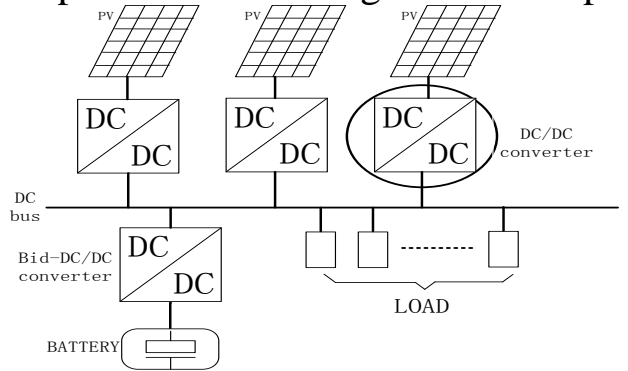

Fig.1 The structure of The stand-alone PV generation system 


\section{II.THE FUNDAMENTAL THEORY OF FUZZY PID CONTROL}

\section{A. The structure of Fuzzy PID controller}

The output variables are $\Delta K_{p}, \Delta K_{i}$ and $\Delta K_{d}$, which comes from input variables that have been handled with fuzzy reasoning,fuzzy solution and quantification.Then,they are added with the initial PID parameters to get new PID control parameters and implement the online adjustment of PID parameters.In the end,the values are get from PID controller.The output control value is $\Delta d$ in the DC-DC circuit.The fig. 2 shows the structure of fuzzy PID controller.

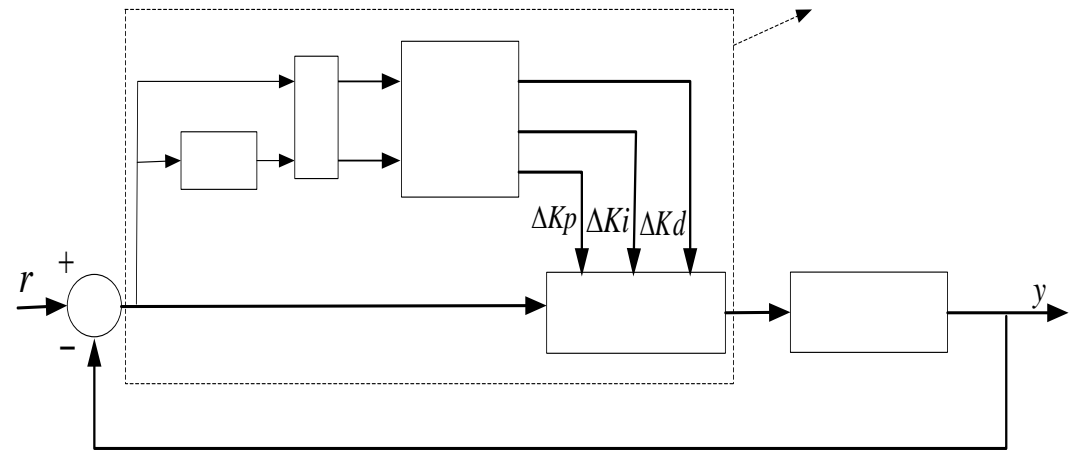

Fig.2 The structure of fuzzy PID controller

\section{B. The design of fuzzy PID controller}

The universe of two input variables and three output variables in the fuzzy controller are designed within [-3,3].All the variables have 7 fuzzy sets, which are $\{\mathrm{NB}, \mathrm{NM}, \mathrm{NS}, \mathrm{ZE}$, PS, $\mathrm{PM}, \mathrm{PB}\}$.And all the input variables and output variables use the triangle membership function.

In the parameters regulation of fuzzy PID control,there are three rules to be considered [4].

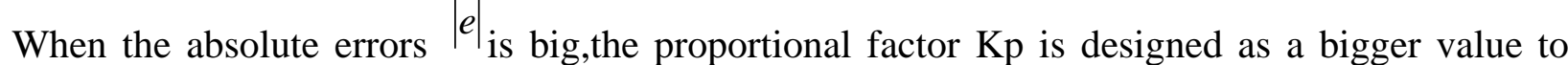
assure that the system has better performance of tracking.In order to prevent the possible differential supersaturation caused by error increasing instantly,the differential factor should be designed as a small value.Besides,the integral factor should be a small value to prevent the system appearing large overshoot.

When the values of absolute error $|e|$ and error rate $\left|e_{c}\right|$ are medium,the proportional factor Kp should be a smaller value , $\mathrm{Kd}$ and $\mathrm{Ki}$ can be approximate values to enhance the system response and reduce the overshoot of system response.

When the absolute error $|e|$ is a smaller value,the proportional factor Kp and integral factor Ki should be bigger values to assure the system performance of steady state.For preventing the output response has oscillation around the set values and considering the anti-interference ability of system,the $\mathrm{Kd}$ should be a appropriate value.The rules of choosing $\mathrm{Kd}$ are:while the $\left|e_{c}\right|_{\text {is }}$

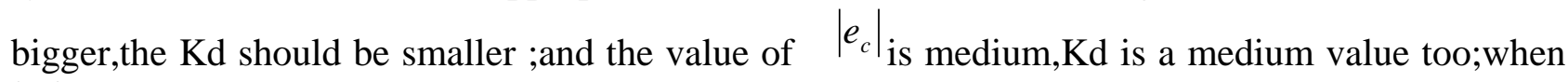
$\left|e_{c}\right|$ is a smaller value,Kd should be a bigger one.

According to the three rules to consider and analyze the system, the fuzzy control rules of $\Delta K_{p}, \Delta K_{i}$ and $\Delta K_{d}$ can be get,which is shown in table 1 [5]. 
Table1 The rules of fuzzy control

\begin{tabular}{|c|c|c|c|c|c|c|c|}
\hline \multirow{2}{*}{$e$} & \multicolumn{7}{|c|}{$e_{c}$} \\
\cline { 2 - 8 } & $\mathrm{NB}$ & $\mathrm{NM}$ & $\mathrm{NS}$ & $\mathrm{ZE}$ & $\mathrm{PS}$ & $\mathrm{PM}$ & $\mathrm{PB}$ \\
\hline $\mathrm{NB}$ & $\mathrm{PB} / \mathrm{NB} / \mathrm{PS}$ & $\mathrm{PB} / \mathrm{NB} / \mathrm{NS}$ & $\mathrm{PM} / \mathrm{NM} / \mathrm{PB}$ & $\mathrm{PM} / \mathrm{NM} / \mathrm{NB}$ & $\mathrm{PS} / \mathrm{NS} / \mathrm{NB}$ & $\mathrm{ZE} / \mathrm{ZE} / \mathrm{NM}$ & $\mathrm{ZE} / \mathrm{ZE} / \mathrm{PS}$ \\
\hline $\mathrm{NM}$ & $\mathrm{PB} / \mathrm{NB} / \mathrm{PS}$ & $\mathrm{PM} / \mathrm{NB} / \mathrm{PS}$ & $\mathrm{PM} / \mathrm{NM} / \mathrm{NB}$ & $\mathrm{PS} / \mathrm{NS} / \mathrm{NM}$ & $\mathrm{ZE} / \mathrm{NS} / \mathrm{NM}$ & $\mathrm{ZE} / \mathrm{ZE} / \mathrm{NS}$ & $\mathrm{NS} / \mathrm{ZE} / \mathrm{ZE}$ \\
\hline $\mathrm{NS}$ & $\mathrm{PM} / \mathrm{NB} / \mathrm{ZE}$ & $\mathrm{PM} / \mathrm{NM} / \mathrm{PS}$ & $\mathrm{PM} / \mathrm{NS} / \mathrm{NM}$ & $\mathrm{PS} / \mathrm{NS} / \mathrm{NM}$ & $\mathrm{ZE} / \mathrm{ZE} / \mathrm{NS}$ & $\mathrm{NS} / \mathrm{PS} / \mathrm{NS}$ & $\mathrm{NS} / \mathrm{PS} / \mathrm{ZE}$ \\
\hline $\mathrm{ZE}$ & $\mathrm{PM} / \mathrm{NM} / \mathrm{ZE}$ & $\mathrm{PM} / \mathrm{NM} / \mathrm{NS}$ & $\mathrm{PS} / \mathrm{NS} / \mathrm{NS}$ & $\mathrm{ZE} / \mathrm{ZE} / \mathrm{NS}$ & $\mathrm{NS} / \mathrm{PS} / \mathrm{NS}$ & $\mathrm{NM} / \mathrm{PM} / \mathrm{NS}$ & $\mathrm{NM} / \mathrm{PM} / \mathrm{ZE}$ \\
\hline $\mathrm{PS}$ & $\mathrm{PS} / \mathrm{NM} / \mathrm{ZE}$ & $\mathrm{PS} / \mathrm{NS} / \mathrm{ZE}$ & $\mathrm{ZE} / \mathrm{ZE} / \mathrm{ZE}$ & $\mathrm{NS} / \mathrm{PS} / \mathrm{ZE}$ & $\mathrm{NM} / \mathrm{PS} / \mathrm{ZE}$ & $\mathrm{NM} / \mathrm{PM} / \mathrm{ZE}$ & $\mathrm{NM} / \mathrm{PB} / \mathrm{ZE}$ \\
\hline $\mathrm{PM}$ & $\mathrm{PS} / \mathrm{ZE} / \mathrm{PS}$ & $\mathrm{ZE} / \mathrm{ZE} / \mathrm{ZE}$ & $\mathrm{NS} / \mathrm{PS} / \mathrm{PS}$ & $\mathrm{NM} / \mathrm{PS} / \mathrm{PS}$ & $\mathrm{NM} / \mathrm{PM} / \mathrm{PS}$ & $\mathrm{NM} / \mathrm{PB} / \mathrm{PS}$ & $\mathrm{NB} / \mathrm{PB} / \mathrm{PB}$ \\
\hline $\mathrm{PB}$ & $\mathrm{ZE} / \mathrm{ZE} / \mathrm{PB}$ & $\mathrm{ZE} / \mathrm{ZE} / \mathrm{PM}$ & $\mathrm{NM} / \mathrm{PS} / \mathrm{PM}$ & $\mathrm{NM} / \mathrm{PM} / \mathrm{PM}$ & $\mathrm{NB} / \mathrm{PM} / \mathrm{PS}$ & $\mathrm{NB} / \mathrm{PB} / \mathrm{PS}$ & $\mathrm{NB} / \mathrm{PB} / \mathrm{PB}$ \\
\hline
\end{tabular}

\section{The design of input variables in fuzzy controller}

Under the MPPT control mode,the input variables of fuzzy controller are error $e(k)$ and error rate $e_{c}(k)$,which can be calculated as follows.

$$
\left\{\begin{array}{l}
e(k)=\frac{P(k)-P(k-1)}{I(k)-I(k-1)} \\
e_{c}(k)=e(k)-e(k-1)
\end{array}\right.
$$

The $\mathrm{P}(\mathrm{k})$ and $\mathrm{I}(\mathrm{k})$ in type(1) are the output power and current of battery in the $\mathrm{k}$ sample point,respectively; $\mathrm{P}(\mathrm{k}-1)$ and $\mathrm{I}(\mathrm{k}-1)$ are the output power and current of battery in the k-1 sample point.

Under the control mode of constant voltage output,the input variables are the error $\Delta U(k)$ and error rate $U_{c}(k)$ between the output voltage of DC-DC converter and reference voltage value(220V), which can be get from type(1),respectively.

$$
\left\{\begin{array}{l}
\Delta U(k)=U(k)-U(k-1) \\
U_{c}(k)=\Delta U(k)-\Delta U(k-1)
\end{array}\right.
$$

In the type(2), the $U(k)$ is the error between output voltage of DC-DC converter and reference voltage value in the $k$ sample point. the $U(k-1)$ is the error between output voltage of DC-DC converter and reference voltage value in the $k-1$ sample point.

\section{III.THE SIMULATION RESEARCH}

The parameters of PV cell are designed as follows:open circuit voltage $V_{o c}: 22 \mathrm{~V}$,short circuit current $I_{s c}: 8.58 \mathrm{~A}$,the voltage of peak power $V_{m}: 17.7 \mathrm{~V}$,the current of peak power $I_{m}: 7.94 \mathrm{~A}$

\section{A. MPPT control}

The surface temperature of PV cell is $25^{\circ} \mathrm{C}$,and the time of simulation is 1s.The initial sunshine intensity of simulation is $1000 \mathrm{w} / \mathrm{m}^{2}$, and the intensity drops to $800 \mathrm{w} / \mathrm{m}^{2}$ in the $0.4 \mathrm{~s}$, besides, it comes to $1200 \mathrm{w} / \mathrm{m}^{2}$ from $800 \mathrm{w} / \mathrm{m}^{2}$ in the $0.7 \mathrm{~s}$. The output power is shown in fig. 3 . 


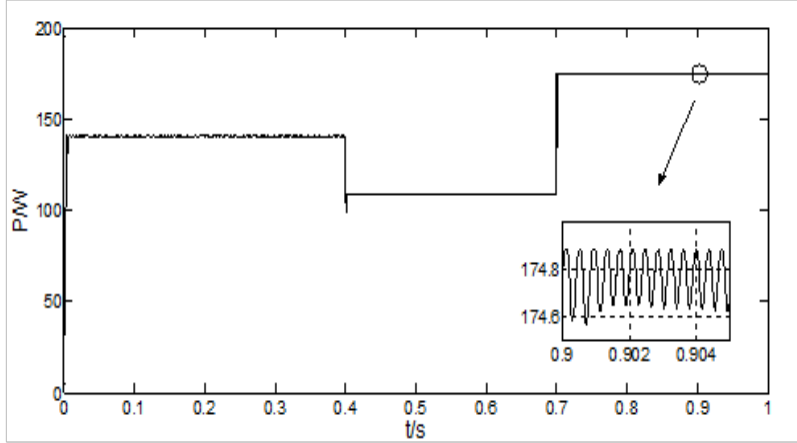

Fig.3 The output power

B. The control of constant voltage output

The time of simulation is $1 \mathrm{~s}$ and the initial output voltage of PV is $50 \mathrm{~V}$.In the $0.5 \mathrm{~s}$, it jumps to 80V.The reference output voltage value is 220V.The voltage output is shown in fig.4.

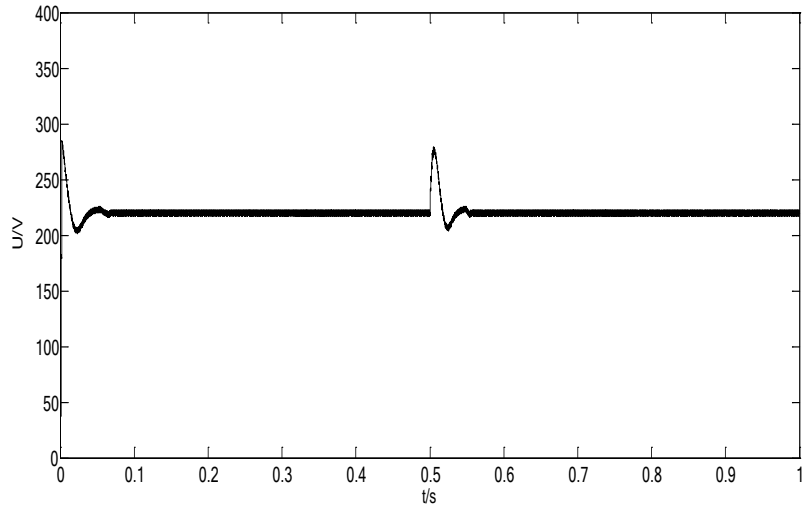

Fig. 4 The output voltage curve of DC-DC converter

\section{The analysis of simulation result}

According to the fig.3,in the control mode of MPPT,the time that photovoltaic cell needs from standby state to MPP is very short.And the time that light rises to(or drops to) MPP suddenly is same.In the steady state,the output power of PV is stable and the fluctuation is very small,which shows that the control algorithm can track MPP rapidly and reduce the oscillation amplitude of steady state power and power loss.From the fig.4,in the control mode of output constant voltage, whether it is in the initial state or in the rising state of output voltage of PV, the output voltage of DC-DC converter can reach the reference voltage and the fluctuation of steady state voltage is small.Therefore, it shows that the algorithm has better performance of dynamic and steady state in the control of constant voltage.

\section{CONCLUSION}

The paper proposes a new algorithm based on fuzzy-PID control,which utilizes the same fuzzy rules to control the converter.It can not only complete the MPPT control,but also complete the constant voltage output control.The proposed algorithm is simulated in Simulink and the result shows that the new algorithm can not only implement the PV MPPT control,but also the constant voltage output control.Under the MPPT control mode,it can track MPPT rapidly and reduce the amplitude of steady-state power oscillation and power loss.In the mode of constant voltage output,it can reach the reference voltage value rapidly and keep small voltage oscillation.The algorithm simplifies the control strategy of DC-DC converter in the PV system and enhances the stability of system effectively.

\section{Acknowledgment}

This paper is supported by National Natural Science Foundation of China (Project Number: 6120 3224), Shanghai Science and Technology Commission Key Program (No.14511101200), Shanghai 
Natural Science Foundation (13ZR1417800), The Foundation of Shanghai Key Laboratory of Power Station Automation Technology (No.13DZ2273800), project of Science and Technology Commissi on of Shanghai ( project number: 12510500800).

\section{References}

[1] ZHANG Li,SUN Kai and WU Tianjin,”Energy conversion and management for DC microgrid based on photovoltaic generation,'Transactions of China Electrotechnical Society,vol. 28, Feb.2013,pp.248-254.

[2] LIAO Zhiling and RUAN Xinbo,"Energy management control strategy for stand-alone photovoltaic power system,” Proceedings of the CSEE, vol. 29,Jul. 25, 2009,pp.46-52.

[3] YUAN Jianhua,GAO Feng and GAO Houlei,”Unified energy control strategy of stand-alone photovoltaic system," Transactions of China Electrotechnical Society,vol. 26, Sup. 1,2011,pp.247-252.

[4] Lu C, Zhang J. Design and simulation of a fuzzy-PID composite parameters' controller with MATLAB[C]//Computer Design and Applications (ICCDA), 2010 International Conference on. IEEE, 2010, 4: V4-308-V4-311.

[5] CHEN Li and HAN Hui,"MPPT control research of photovoltaic system based on the fuzzy PID control,” Electronic Design Engineering,vol. 21,Jan.2013,pp.67-70. 